Open Access

\title{
A qualitative study on learning trajectories of non-native Chinese instructors as successful Chinese language learners
}

Shijuan Liu ${ }^{1 *}$ (D) and Fu Wang ${ }^{2}$

\author{
* Correspondence: sliu@iup.edu \\ 'Department of Foreign Languages, \\ Indiana University of Pennsylvania, \\ Room 456, Sutton Hall, Indiana, PA \\ 15705, USA \\ Full list of author information is \\ available at the end of the article
}

\begin{abstract}
This paper reports a qualitative study on the Chinese language learning trajectories of non-native Chinese instructors as successful Chinese language learners. While some literature has been found on studying good learners of English and other languages, there is a lack of research on studying good learners of the Chinese language, especially on their life-long Chinese learning process. Six active instructors teaching Chinese at K-12 schools or universities in the United States, whose native language is English, were interviewed on a one-on-one basis with an auto/biographical approach. This approach, as one type of narrative inquiries under a qualitative paradigm, has been increasingly used in the study of English language learners. Findings of the study include that the six participants all had experiences studying in Greater China, and all held lifelong learning attitude as well as demonstrated various self-regulation strategies with strong self-motivation and dedication. While they all took Chinese classes at college, only two of them studied prior to college, which is encouraging for Chinese learners who were unable to learn Chinese from an early age. This study helps to fill the gap in literature on good language learners of Chinese, and provides educational implications for Chinese language learners, instructors, researchers, and other stakeholders.
\end{abstract}

Keywords: Language learners, Chinese language learning, Learning experience, Learning process, Non-native instructors, Auto/biographical research, Qualitative study

\section{Introduction}

The past decade has seen a rapid expansion in the learning and teaching of Chinese worldwide. In the United States alone, according to Tsung and Cruickshank (2011), there are over 500 schools and universities offering Chinese language programs. In addition, the website of Hanban (2017) shows that 110 Confucius Institutes and 501 Confucius Classrooms have been established in the United States to respond to the increasing needs of local institutions.

As some scholars (e.g., Brecht \& Walton, 1994; Everson \& Shen, 2010a) have pointed out, in addition to language programs, it is also critical for the growth of a language field to conduct research on problems and issues germane to the field. Compared to the research on teaching English to speakers of other languages (TESOL), studies on teaching Chinese to speakers of other languages, as noted by many researchers (e.g., Duff et al., 2013; Han, 2014), are still limited.

(c) The Author(s). 2018 Open Access This article is distributed under the terms of the Creative Commons Attribution 4.0 International License (http://creativecommons.org/licenses/by/4.0/), which permits unrestricted use, distribution, and reproduction in any medium, provided you give appropriate credit to the original author(s) and the source, provide a link to the Creative Commons license, and indicate if changes were made. 
This article reports a qualitative study that the authors recently conducted on studying non-native Chinese instructors ${ }^{1}$ as good learners of the Chinese language.

\section{Literature review}

\section{Research on good language learners}

Research on good language learners is in alignment with the notion on best practice in other professional areas such as business and health care (Norton \& Toohey, 2001). The beginning of the line of research on good language learners (GLL) is often credited to the work of Joan Rubin's TESOL Quarterly article published in 1975 (Griffiths, 2008a). Rubin's (1975) rationale of studying good learners, was that "if we knew more about what the 'successful learners' did, we might be able to teach these strategies to poorer learners to enhance their success record" (p.42). Based on her experience learning several languages and teaching English as a second language, she coauthored the book entitled How to Be a More Successful Language Learner, in which Rubin and Thompson (1982) proposed 14 strategies for becoming a successful language learner, such as "find your own way," "be creative," "make your own opportunities," "learn to live with uncertainty," "use mnemonics," "let context help you," and "learn formalized routines." According to Cohen (2008), Rubin's idea was very original at that time, since "there was no focus on what the learners were doing" (p.8), and to some degree, was comparable to the Wright brothers telling people about their ideas for a "flying machine."

In addition to Rubin, earlier advocators on GLL research in the 1970s include Stern (1975), Cohen (1977), and others. One rigorous GLL study was conducted by Naiman and associates from the Ontario Institute for Studies in Education of Canada in 1978. Their study included two parts. In the first part, the researchers interviewed 34 adults on their second language learning experiences. They found that despite the uniqueness of their individual language learning career, there were many common experiences and characteristics among the interviewees. For example, the good learners were actively involved in the language learning process, and found ways to overcome linguistic, affective, or environmental obstacles. They also monitored their own practices, performances, and involved themselves in communication. The second part of the large-scale study involved classroom observations of students in the 8th, 10th, and 12th grades learning French as a second language in Toronto. They found that attitude and motivation were the best overall indicators of success for language learning in most instances. Brumfit (1995) comments that the findings of Naiman and his coauthors stood up well for the subsequent research, and "the only really significant addition is the view that good language learners are flexible and vary their learning strategies" (p.ix).

Since then, a number of works (e.g., Ellis, 1994; Cohen \& Macaro, 2007; Graham, 1997; Macaro, 2006; Oxford, 1990; Stevick, 1989) have been published on further study of good learners and their strategies. The edited book Lessons from Good Language Learners by Griffiths (2008b) groups the 23 chapters from various contributors into two parts: (1) Learner variables and (2) Learning variables. The contributors in this edited book summarized research on 14 variables concerning language learners such as age, personality, gender, learning style, motivation, metacognition, and autonomy, as well as 12 variables related to language learning, such as vocabulary, 
grammar, pronunciation, listening, speaking, reading and writing. They also provided implications for the teaching/learning situation and questions for ongoing research. In the concluding chapter, Oxford and Lee (2008) pointed out that language learning was "a difficult journey across a demanding landscape by extremely complex beings who behave in completed ways" (p.315), and many questions still need to be further investigated.

In light of sociocultural theory (e.g., Hall, 1995; Lantolf, 2000; Vygotsky, 1978) and research on communities of practice (e.g., Lave \& Wenger, 1991), Norton and Toohey (2001) point out that "understanding good language learning requires attention to social practices in the contexts in which individual learn L2s" (p.318), and urge researchers to pay attention to how communities and their practices are structured. Their position is echoed in the book Social Turn in Second Language Acquisition by Block (2003). In his book, Block examines the "Input-Interaction-Output" model (see, for example, Gass, 1997) and suggests a broader, more socially informed and interdisciplinary approach to second language acquisition (SLA) research. Block's "social turn", as mentioned in his book, is based on discussion of many researchers on this topic since mid-1990s (e.g., Brumfit, 1997; Firth \& Wagner, 1997; Hall, 1995, 1997; Lantolf, 1996; Rampton, 1997a, 1997b; van Lier, 1997), and some of the cited articles are available in the special issues of the Modern Language Journal (1997 Autumn issue) and International Journal of Applied Linguistics (1997 June issue).

In addition, most of the early work on language learners, according to Pavlenko and Lantolf (2000), were solely on linguistic proficiency. They suggest that a language learner is more a participant in language socializations, who crosses the border into the domain where selves and worlds are reconstructed. Hanauer (2011) further articulates that a language learner is "a socially and culturally contextualized individual with a rich, extended history of personal experience" and language learning, therefore, involves "an interaction with everything that makes up the experience and understanding of the learner, including issues of identity and self-perception" (p.109). Benson and Cooker (2013) continue to advocate the use of sociocultural approaches to study identity, agency and autonomy of language learners, the socially constituted individuals.

\section{Related studies on Chinese language learners}

As Tsung and Cruickshank (2011) state, while there is a strong tradition of linguistics research in Chinese, empirical research investigating the learning and teaching of Chinese as a second/foreign language is relatively new, compared to studies on teaching and learning of English or other commonly taught European languages. Some empirical studies have been found on Chinese language learners. For instance, Jin (1989) investigated whether or not a composite theory of universals and typological parameters could account for interlanguage process in terms of developmental patterns, learning difficulty, and possibility of transfer based on her data from 86 adult Chinese learners. Everson and Ke (1997) investigated reading strategies of intermediate and advanced learners of Chinese, and Winke (2007) studied the effects of L1 background on L2 Chinese learners' tonal production. In addition, Wen (2010) studied acquisition of 
the displacement Ba-construction by English-speaking learners of Chinese, and Yang (2014) examined the effects of pragmatics instruction on L2 learners' acquisition of Chinese expressions of gratitude.

The Chinese Language Teachers Association (CLTA)'s monograph Research among Learners of Chinese as a Foreign Language edited by Everson and Shen (2010b) includes eight empirical studies. Most of them focus on cognitive aspects of the second language acquisition of Chinese. In the preface of her edited book Studies in Second Language Acquisition of Chinese, Han (2014) points out that while research on second language acquisition of Chinese has existed, for a long time it has been "confined to a narrow range of topics and perspectives" (p.ix). The book includes six studies in second language acquisition. One of them was by Jin (2014), which investigates peer/group interaction in a Chinese study abroad context from a sociocultural perspective based on qualitative data (e.g., weekly interviews, informal observation and participants' weekly reflective journals) collected from 11 study abroad students. One finding of her study was that peer/group interactions in both L1 and L2 "played a vital role in the study abroad program, particularly for lower level learners at the beginning of the program" (p.72).

It is worth noting that with increasing exchanges between China and other countries including the United States there is a growing body of literature addressing study abroad experience of the Chinese language learners. For instance, Tseng (2006) investigates language gain in grammar, listening, and reading by second year non-native students of Chinese in the study abroad and domestic programs. Liu (2010) describes a model that integrates an at-home preparation intensive summer program with a shortterm, study abroad summer program to increase students' Chinese-language proficiency, cultural awareness, and personal career development. Qin (2014) studies the impact of culture in five communicative elements (namely, roles, place, time, audience, and scripts) based on data she collected from real-life interaction through shadowing 20 American learners of Advanced Chinese when they were participating in a study abroad program in China.

Compared to the hundreds of studies on various aspects of TESOL, as many scholars (e.g., Cruickshank \& Tsung, 2014; Han, 2014) have pointed out, more empirical research is needed on the study of teaching and learning Chinese to speakers of other languages. In addition, review of the literature also indicates that there is a lack of research on good language learners of Chinese. Stevick (1989) interviewed seven language learners whom he considered were successful with their foreign language learning. One was a Chinese learner, who was a diplomat under the given pseudonym Bert. The findings of his interview with Bert were grouped into two parts: (1) Audio-lingual-style activities, such as intensive mechanical drill, and memorization of texts; (2) Other activities, which included such activities as paraphrasing as a learning technique, and meaningful memorization of texts technique.

The report by Prescott and Orton (2012), entitled Good Learners of Chinese - Profiles of Students in Secondary Schools, is the only study that we found on studying good learners of Chinese. The two Australian researchers interviewed 14 students to understand the reasons for their success. The students, aged between 13 to 18 years old from six schools in Australia, were identified by their Chinese language teachers as good oral language learners. Each interview lasted approximately $30 \mathrm{~min}$ and was analyzed 
through such lenses as family influences, personal attitude to Chinese language and culture, as well as practices they engaged in. Some of their findings include that the students all "greatly enjoy the challenges it offers despite the work it takes", and they all benefit from "support and a positive attitude to their study from their family" (p.4). No previous study has been found on studying the long-term language learning experience of good Chinese learners yet. Our study is intended to fill this gap.

One critical element of studies on GLL is how to define "good learners". For instance, in the aforementioned Naiman et al. (1978) study, the good learners were recommended as proficient learners by the researchers' acquaintance or through the researchers' own connections. The researchers clearly reported that they did not give the participants any proficiency test to validate.

In the present study we decided to choose non-native Chinese language teachers as our good language learners based on the following two considerations. First, their success in Chinese language learning is validated by their profession, which is more convincing than informal evaluation (e.g., recommendation by acquaintance) or a single proficiency test. Second, while many English native speakers can be found in the profession of teaching Spanish, French, and other commonly taught languages, there are much fewer English native speakers found in the work force of teaching Chinese in the United States, as also noted by Everson and Xiao (2009). A significant advantage of having local teachers as language instructors, as Snow (2007) identified, ${ }^{2}$ is that they can "inspire students to believe that success is possible" and provide students with a good role model (p.8). In addition, study of the journeys of the Chinese instructors who are Chinese language learners themselves can provide inspirations to other Chinese learners who have the potential and interest in becoming Chinese language instructors.

Two overarching questions guided this study: (1) what are the life-long Chinese language learning processes of these non-native Chinese instructors? and (2) what are the common experiences shared among them regarding their Chinese language learning?

\section{Methods}

Review of the literature on Chinese language learners also shows that fewer studies investigate learners as socially and culturally contextualized individuals with naturalistic and qualitative (including the narrative inquiry) approach. As Duff et al. (2013) point out, "most existing studies analyze acquisition from a (psycho) linguistic or cognitive perspective rather than from a socialcultural or social-practice perspective" (p. 12). Furthermore, similar to what some scholars (e.g., Hanauer, 2011; Pavelenko \& Lantolf, 2000) commented on the early studies on language learners in TESOL, very limited research has been found on studying learners' learning process holistically including their identity, autonomy and other involved aspects in addition to their language proficiency.

To holistically understand the various dimensions of the complex language learning process and describe the experiences of language learners with richness, researchers (e.g., Bell, 2002; Benson 2005, 2011; Firth, A.\& Wagner, J., 1997) suggest conducting qualitative research. Qualitative research, as Roberts (2002) explains, has "a 
number of features stemming from its philosophical and theoretical approach to the social world, including remaining close to the experiences and views of the researched" (p.2).

\section{Auto/biographical research method}

Benson (2005) coined the term "(auto) biography" to refer to both biography and autobiography. According to him, (auto) biography has often been used in different terms in TESOL and Applied Linguistics, such as narrative research, narrative inquiry, ethnographic approach, "narrative study of lives, autoethnography, life history, and autobiography."

Pavlenko (2007) categorized autobiographic narrative data into three types: (1) Diaries and journals by L2 learners; (2) Linguistic biographies and autobiographies, collected through interviews in the North American tradition; and (3) Language memoirs, which were published linguistic autobiographies. According to Bell (2002), narratives allow researchers to understand experience and "present experience holistically in all its complexity and richness" (p.209). Benson (2011) concurs and argues that one of the strengths of narrative research is its potential to provide insight into long-term language learning experience that cannot be investigated in real time.

Wang (2014) used "autobiography narratives" to study four professors who were international faculty at an American university regarding their life-long English learning experiences. The narratives were collected by approximately one-hour long interviews of each interviewee. At the beginning of the interview, he prompted the interviewees to reflect on their English learning experience as if they were writing a language memoir before asking them to elaborate what they wrote down in the memoir.

Duff and her coauthors (2013) reviewed existing (auto) biographical accounts of learning Chinese. In addition to available case studies of American or Canadian nonheritage leaners of Chinese, Duff and her coauthors also reviewed books written in memoir genre such as Fallows (2010) and autobiographical accounts of sojourners in China such as McDonald (2011). As pointed out by Duff and her coauthors (2013), there is "almost no studies framed by socialcultural theory or narrative inquiry have been conducted on the acquisition of Chinese by English speakers" (p.17) and few studies have provided an in-depth and contextualized analysis of individual learners' motivations and goals for choosing to study Chinese and "their longer-term trajectories as Chinese learners" (p.13).

This present study adopted a similar method as used by Wang (2014) to study the life-long Chinese learning experience of Chinese language instructors who are native English speakers. The term "narratives" in this study is used to refer to similar qualitative data that Wang (2014) in his study, which consisted of (1) the oral interview with the participants, and (2) the outline written down by participants about their language learning history as if writing a language memoir at the beginning of the interview.

However, in this paper, notably, we decided to use the term "auto/biographical" instead of "autobiographical" used in Wang (2014) based on the following two considerations: (1) to describe the nature of the narratives more accurately. The narratives were not completely produced by the persons being researched but were collected through interviews between the researcher and the participants. Using the term 
"auto/biographical" can help avoid confusion with those that are truly autobiographical, such as the autobiographical narratives used in Fang (2006), in which she examined her own experiences of learning languages and teaching English in China; (2) to reflect the role of researchers as "auto/biographer" in this type of research. As suggested by Roberts (2002), in the collection of their stories through interviewees, the interaction between the researcher and the interviewees not only "is helping the interviewees to reflect and give form and structure to their lives", but also "helping researchers to begin to draw on their own experiences" (p.13).

\section{Participants}

We used two criteria in selection of participants: (1) the participant was an English native speaker with non-heritage background, and (2) the participant taught the Chinese language at a formal K-16 institution in the United States as part of his or her job responsibilities.

A number of potential participants who met the above two criteria were approached. Six of them agreed to participate in the study. Three of them taught Chinese at K-12 schools, while the other three taught at the post-secondary level. Three were male and three were female (see Table 1 for more information about the six participants).

\section{Data collection and analysis}

The six participants were interviewed on a one-on-one basis between July and November of 2014. The first interviewee was a college professor whom the first author had known personally through other circumstances. The interview was conducted by the second author alone via phone. Before the interview, the two authors discussed the interview protocol thoroughly. After the interview, the first author listened to the audio recording of the interview and analyzed the data separately from the second author. Then the two authors compared and contrasted their analysis for the purpose of ensuring the reliability of the qualitative data analysis.

The other five participants were also identified by the first author through professional network and/or at various professional occasions (e.g., conferences). Because the first author is a Chinese language instructor herself, it is easier for her to build trust and rapport between the researcher and the interviewees, which is important, as

Table 1 Summary of the information on the participants and data collection

\begin{tabular}{|c|c|c|c|c|}
\hline Level & Name (pseudonym) & Gender & Work place and teaching duties & Data collection \\
\hline \multirow[t]{3}{*}{$\mathrm{K}-12$} & Mr. Dylan & Male & $\begin{array}{l}\text { A private high school, teaching Chinese } \\
\text { language and history courses }\end{array}$ & Onsite \\
\hline & Ms. Pam & Female & A private high school, teaching Chinese & Distance (Skype) \\
\hline & Mr. Andy & Male & $\begin{array}{l}\text { A private high school, teaching Chinese } \\
\text { (till 2014) }\end{array}$ & Distance (Skype) \\
\hline \multirow[t]{3}{*}{ Postsecondary } & Dr. Peter & Male & $\begin{array}{l}\text { A public university, teaching Chinese } \\
\text { language, Chinese and Japanese } \\
\text { literature and culture courses }\end{array}$ & Distance (Phone) \\
\hline & Ms. Katy & Female & $\begin{array}{l}\text { A private liberal arts college, teaching } \\
\text { Chinese language }\end{array}$ & Distance (Phone) \\
\hline & Dr. Sara & Female & $\begin{array}{l}\text { A private university, teaching Chinese } \\
\text { language }\end{array}$ & Onsite \\
\hline
\end{tabular}


mentioned by Roberts (2002) for conducting the auto/biographical research. The five interviews were all conducted by the first author alone either onsite or at distance over the phone or via Skype.

The information of the participants and data collection means is summarized below. To protect their true identities, each participant is given a pseudonym, and the detailed information of their working places and related educational backgrounds is intentionally not specified.

At the beginning of each interview, participants were given some time to reflect on their Chinese language learning experiences as if they were writing a memoir. They were asked to write down the outline on a given paper with such prompts as how many chapters would you write? What would be the headings for each chapter? (See the Appendix for details) For remote interviews, the interviewees were asked to share what they wrote (or typed) via email before the interview started. During the interview, the researchers mainly went over with each participant the outline of the memoir that $\mathrm{s} /$ he wrote down (or typed) on paper. The researcher only gave necessary prompts such as what was your rationale to identify this period of time as a single chapter?

It is noteworthy that since the goal of this study is to gain an overall picture of the learning trajectory of each participant, there is usually little need for the researchers to ask additional prompts during the interview. In addition, supported by the rationale stated in the literature review (e.g., Benson, 2005; Hanauer, 2011), we view every single participant as a subject who tried to find meaning of his or her life and career, and therefore, we tried to keep our intervention to a minimum, and only asked for confirmation and requests for further details occasionally when we deemed it as important and necessary.

The six interviews were conducted in a mixture of Chinese and English based on the interviewees' preference. Each interview lasted for about one hour, and was audio recorded. A detailed summary was written right after each interview, and the recorded interview was later transcribed verbatim. Similar to handling the first interview, the two researchers first analyzed the interviews separately and then compared and contrasted what they found through ongoing discussions. As suggested by Johnson (1997), descriptive validity and interpretive validity were emphasized in this quality study. The recordings and transcripts of the interviewed were reviewed multiple times for themes and patterns, and the data analysis results were shared with participants for feedback and accuracy check.

\section{Results and discussions}

Similar to what Naiman and his coauthors found from their interviews in 1978, our findings showed that while the six participants achieved their success in different ways, there were several shared experiences and factors across their narratives. Additionally, in light of our review of the literature, especially the theoretical relevance of "social turn", we view the language learning as a process that involves not only cognitive and psychological factors but also emotion and identity construction under the social-cultural context. One great strength of the auto/biographical approach, as previously discussed, is to allow researchers to capture participants' long-term language learning experiences in all its complexity and to understand their learning 
process holistically. While there are also some specific themes we found from the data analysis, such as textbooks used by participants and their recommendations, due to the limitation of length and scope of a paper, we decided to give more focus on reporting the participants' life-long learning experiences in a macro perspective so that readers can get a holistic and overall picture of the learning trajectory of the participants.

\section{(1) Culture, community, family - the initiation}

Participants in this study all shared how their Chinese language journey began. Dr. Peter, Mr. Dylan, and Dr. Sara mentioned that their motivation in learning Chinese started with their interest in Eastern philosophy. According to Dr. Peter, he always enjoyed reading books on Confuciusm and Buddhism, and he chose to study Chinese language for the purpose of learning Chinese philosophy and culture in greater depth. Mr. Dylan recalled that one of his high school teachers advised him to read the related thoughts of ancient Asian philosophers from China and India for his senior project. After reading Lun $Y u$ (论语,The Analects) of Confucius and a number of books on Buddhism, he realized that his view of the world was limited to Europe, and he then decided to learn more about Asia in college. Similarly, Dr. Sara mentioned that she did an independent study on philosophy in her high school in order to find different ways of thinking, through which she became interested in traditional Chinese philosophy. Notably, Mr. Dylan shared that he initially was interested in both Chinese and Japanese languages, and later chose Chinese over Japanese because he was more intrigued by communism and Chinese politics.

Most of the participants commented that their interest in Chinese was also influenced by their families, friends, and communities. For example, Dr. Peter mentioned that he grew up in a college town, where he had opportunities to meet with international faculty, including some from Taiwan, through his family connections. Dr. Sara mentioned that her mother was a French language teacher, and she always had an interest in foreign languages. Mr. Andy recalled that his initial motivation in learning Chinese was rather accidental. In the summer before he went to college, a few business friends of his father from Taiwan visited his family. During his conversation with them, they encouraged him to "try Chinese language in college" since he had already studied other foreign languages in high school. Ms. Pam's decision was largely shaped by her father who believed that Chinese and Spanish were the most useful languages to learn. She also remembered that in 7th grade she had a classmate and good friend whose family was from Taiwan, and she was fascinated by the Chinese culture that she experienced through her friend's family, such as the delicious food her family made, and the beautiful decorations for celebration of Chinese New Year in her house. Ms. Katy's case was different than other participants in that she was born in Taiwan when her family lived there because of her father's work.

The motivation of learning a language has been an important topic in all language study research (Dörnyei \& Ushiota, 2013; Gil, 2014; Noels et al., 2000; Rubin, 1975; Wen, 1997). Motivation is listed by Rubin (1975) as one of three essential variables for good language learning. The intrinsic interest in Chinese culture that initially motivated the participants to learn Chinese language is consistent with the literature. For instance, 
Wen (1997) found in her study of 77 learners that interest in learning Chinese culture and understanding one's heritage was the first factor for students to start to learn Chinese, and this intrinsic motivation factor was in strong collation with student learning outcomes. Additionally, the family and community factors found in our study are also consistent with what Prescott and Orton (2012) found from the motivation of good learners in secondary schools.

Gil (2014) found that economic competitiveness, political competiveness, and population competiveness most strongly supported the "macroacquisition" of Chinese based on his survey of language learners enrolled in universities in Australia and China as well as his study of a range of secondary sources. The three types of competiveness, however, were not mentioned by participants in our study. This finding probably is related to the fact that most participants in our study began to learn Chinese between the 1970s and 1990s when the economy of China was still less developed. On the other hand, this difference might imply that intrinsic motivation is more important for good language learners at least in this study.

Considering students' initial motivation to learn a new language is related to the enrollment of beginning language classes, findings related to this theme have implications not only for researchers and practitioners but also for administrators and other stakeholders. Given the importance of the intrinsic motivation and the roles that family and community play, Chinese instructors and program coordinators at K-16 levels are encouraged to continue to organize co-curricular and extracurricular activities to promote Chinese language and culture on campus and in the community. It is also advisable to collaborate with local Chinese communities and colleagues from related disciplines (e.g., history, philosophy, arts) as well as seek support from administrators and other stakeholders.

\section{(2) Chinese learning in college (home institution) - the foundation}

Among the six participants, only two of them (Ms. Katy and Ms. Pam) studied Chinese before college. According to Ms. Katy, because her parents were living in Taiwan and "there was no American school or international school at the time nearby," she attended regular schools for local Taiwanese children from four years old to eight years old (preschool to 3rd grade). Ms. Pam started to learn Chinese during her junior and senior years at high school along with studying Spanish for four years. Ms. Pam recalled that it was difficult to find a Chinese teacher in her hometown area back in the 1980s. Her Chinese teacher was an old gentleman who used to be a spy in World War II and studied Chinese in his own way. It was an age wherein there were "no cassette tapes nor internet," not to mention "language partners" whatsoever.

Except Dr. Peter who was an English major in college, the other five participants all majored in Chinese or Asian Studies as undergraduate students. According to Dr. Peter, there was no professional Chinese instructor available at the university he attended in late 1970s. His first Chinese instructor was a person from the field of arts who studied Chinese for three years. The other five participants all began to learn Chinese from their college freshman year. Dr. Sara went to study Chinese in Taiwan right after her freshman year, while the other four participants (Mr. Dylan, Ms. Pam, Mr. Andy, and Ms. Katy) all studied Chinese in their home institutions for the first two years before 
studying abroad in their junior year. They all recalled that the sizes of their Chinese classes were small, especially the upper level Chinese classes.

According to Mr. Andy, the two years of studying Chinese at his college in the United States helped him build a solid foundation for his Chinese learning, and it did not take him long to adjust to the immersive Chinese environment when he arrived in Taiwan. This finding is consistent with what Liu (2010) points out, that is, the at-home preparation program, if well-designed can help build students' confidence and allow them to benefit more from interacting with native speakers during their study in China.

Rubin (1975) listed age as one of the factors requiring further research. Gass et al. (2013) summarized literature on age differences in language acquisition, including the discussions on Critical Period Hypothesis $(\mathrm{CPH})$, which was originally formulated by Lennenberg (1967). Marinova-Todd et al. (2000) cautioned researchers and others not to jump to conclusions about early learning, and proposed that age differences may reflect more the situation of learning than a capacity for learning. While it is apparent that there are many advantages identified in learning a language at an early age (Birdsong, 1999; Gass et al., 2013), our findings show that it is still possible for learners to achieve highly satisfactory level of Chinese proficiency in their academic career through hard work, as exemplified by the experiences of four participants in this study, who didn't begin their Chinese learning journey until college due to various reasons.

\section{(3) Study abroad experience - the immersion}

The six participants all had experience studying Chinese in Greater China. Dr. Peter went to Taiwan for one summer and stayed with a local family after graduating from college. He took some Chinese language and culture classes at a university in Taipei while teaching English part time. Ms. Pam studied at Tsinghua University in Beijing in the summer after her sophomore year and studied Chinese at another university in Beijing for one year on a Chinese government scholarship. After her graduation she also went to China multiple times. Mr. Dylan studied at Beijing through the Associated Colleges in China (ACC) program during the summer and fall semester of his junior year, then studied in Taiwan for a number of years after graduating from college. He also earned a master's degree and nearly finished a doctorate degree in Chinese history while in Taiwan.

Both Mr. Andy and Ms. Katy studied at the Inter-University Program (IUP) for Chinese Language Studies in Taipei. Dr. Sara studied Chinese at Taiwan Normal University for her sophomore year and returned to Taiwan again to continue her Chinese learning while teaching English part time after her graduation. She later studied Chinese at Beijing University for another year while conducting research for her graduate study. Similarly, after graduation Ms. Katy studied Chinese intensively in Nanjing University as part of her graduate study for one year.

Zeng (2011) states that study abroad "is an important rite of passage during which language learners apply what they have previously acquired from classroom to more authentic social settings" (p. 32). The six participants in this study all spoke highly of their study abroad experiences. According to Mr. Dylan, studying in the ACC immersion program was very helpful, and was a breakthrough for his Chinese 
communication proficiency. As he explained, the structure of the Chinese classes offered at his college in the United States was good, which made him want to learn Chinese. He had Chinese every week day, three days for lecture, and two days for drills. He also went to lab to do required listening and recording. He recalled that he went to the language lab frequently and listened to those audiotapes a lot during his first two years of learning Chinese at his college, but he still felt that he was not making much progress and not proficient enough to communicate fully in Chinese. He stressed a couple of times during the interview that when he studied in the language lab he "had a strong feeling of going to China" and could not wait to take part in the immersion environment as soon as possible.

According to Dr. Sara, her study abroad experience in Taiwan during her sophomore year not only helped improve her Chinese proficiency but also helped in deciding to major in Chinese. Ms. Pam further stated that studying in China even helped her change her personality in addition to improving her Chinese. She said that she was very introverted and not confident before studying in China. During her study in China she would need to make many decisions herself. In addition, she had the time and freedom to explore her interests, such as studying Buddhism and Taiji. These experiences made her become more confident and extroverted, and had a large impact on her professional career.

Mr. Dylan, Ms. Katy, and Dr. Sara all commended the good structure of the study abroad program they attended. According to Mr. Dylan, the ACC program had "very good curriculum." Students in the ACC program lived in dorms on campus and pledged to speak Chinese all the time with classmates and roommates. There were four-hour Chinese language courses taught in the morning, and cultural activities in the afternoon with excursions arranged over weekends. Similarly, Ms. Katy mentioned that the IUP Taipei program was "very rigorous." The instructors were selected by the program director. The ratio of instructor to students in the combined session was one to three, and in the single session one to one. The curriculum was topic oriented, covering various topics, such as stories, novels, radio and broadcast programs.

While Dr. Peter did not study in Greater China before he graduated from college, he found that the immersion program he attended at Middlebury College was "really very helpful" for his Chinese learning. According to him, the summer Middlebury program was total immersion. Students were asked to speak Chinese all the time, "except, in a situation where, like medical emergency or something like that." Professors were selected from different universities to teach courses, which were "highly structured and very demanding."

Notably, in addition to the immersion program, Mr. Dylan shared that using authentic Chinese books to study history was also critical for his Chinese learning. According to him, when he studied Chinese in Taiwan after he graduated from college, he found the classes did not meet his personal needs and the class setting (i.e., studying with other students) did not fit him any longer. He then decided to have tutors help him study Chinese history through books for native speakers. He felt that there was huge improvement for his Chinese and wished that he could have done this type of study earlier. After he was admitted to the M.A. program in Chinese History at a Taiwanese university, he studied with native speakers and read books all in Chinese. He recalled that it was challenging for him in the beginning. 
According to him, he had to finish reading one book per week while in the past it could take him the whole semester. For writing, he would need to write a report in 10,000-40,000 words in Chinese while his Chinese language classes usually just required some paragraphs. Because the teacher and classmates were all native speakers, he would need to understand the lecturing and participate in the small group discussions in Chinese, which challenged his listening and speaking skills as well. He summarized that he used the Chinese language as a tool for him to study history, and in the past he had used it as a travel tool. His case is consistent with what Zeng (2011) found in that the level "'advanced' marks a transition from learning a language to learning in the language", and studying abroad facilitates learners' use of the language to accomplish their higher professional goals (p.ii). In addition, Mr. Dylan's success in improving his Chinese proficiency through studying authentic history books adds to the related literature (e.g., Grabe \& Stoller, 1997; Krashen, 1982; Stoller, 2002, 2004) regarding the advantages of using content-based instruction for language learning.

\section{(4) Life-long learning - dedication, self-regulation}

All participants indicated that language learning is a life-long learning process either explicitly or implicitly. A couple of them used the well-known Chinese idiom, Huo dao lao, xue dao lao (活到老学到老, Live till old, learn till old), to describe it. For instance, while Ms. Katy has achieved native-level Chinese proficiency through her life-long learning process since her childhood, she mentioned that there were still many things for her to learn, such as the various ways of closing for writing Chinese letters with classical terms. She said her Chinese was not good when it came to writing business letters, and stressed that she could "do Chinese well but not at the very native level." To continue to improve her Chinese, she communicated with her Chinese colleagues in Chinese. She saved all of the written communications with Chinese friends and colleagues to study the beginning and the ending as well as how native Chinese speakers communicated. She also mentioned that she had an officemate who was originally from Taiwan to help correct her Chinese while she helped her with English.

Likewise, Dr. Peter mentioned that as a non-native speaker, he needed to broaden his vocabulary throughout his whole life. In addition, while it was hard to eliminate accent, one could keep on improving to become close to the native level. He mentioned that there were electronic dictionaries and many Internet resources that one could use for learning a language nowadays. He also explained that learning Chinese had to be a lifelong process because there were many different dialects and variations of Chinese from different geographical regions and historical periods.

Most of the participants mentioned that, to learn Chinese very well, one needs to be highly self-motivated, stay focused, and make special efforts especially when studying in a non-Chinese environment. As Mr. Andy explained, "in the United States it is an English environment, many [Chinese] people speak English with you even though you know Chinese. There were so many Chinese who learned English for so long and they spoke English better than American speaking Chinese." He stressed that one would need to make especial effort to keep up one's Chinese in the United States.

Similar to what Naiman and his coauthors (1978) found from their interviews of good learners, participants in this study also showed that they were actively involved in their 
language learning process and found ways to overcome linguistic, affective and/or environmental obstacles in their learning. Based on related research on self-directed learning, autonomy, self-management, and self-efficacy, Oxford (2010) discussed the importance of self-regulation in detail and presented a strategic self-regulation model of language learning. Participants in this study showed strong self-regulation in their Chinese language learning careers. For instance, according to Dr. Peter, one would have to have sufficient determination to deny extraneous activities, such as foregoing some social activities when studying in a non-Chinese environment. He recalled that some students took trips to Montreal during breaks in the summer immersion program at Middlebury College, but he chose not to because he gave priority to his Chinese learning and could not find additional time. As he recalled:

Sometimes your social life suffers a little bit... And then, it takes so much of your time - fortunately, I'm not kind of person who had a whole lot of hobbies, like going fishing or whatever.... I think for some individuals who aren't able to focus that much of their time and energy on one type of study or one course of study such as Chinese language, it would be difficult... You can also look at this, well, this is a phase in my life that, eventually when I get to establish a career, I'll be able to have a more normal, social life, and have this intense study behind me.

Dr. Peter also mentioned that when he travelled to Taiwan in the summer, he tried to speak Chinese all the time, and avoid those who tried to speak English with him. Mr. Dylan concurred and shared that when people tried to practice English with him, he told them that he was from France, a trick taught by one of his teachers. Similarly, Ms. Pam said that when she studied Chinese at Beijing, she and her classmates tried to speak Chinese with each other all the time. She remembered that her roommate was from Switzerland. Although her roommate could speak English they both decided to speak Chinese with each other. She also had a classmate from Thailand who had studied in the United States before, but he did not speak with her in English at all. When she found out later that he could speak English well, he told her that his purpose for studying in China was to learn to speak Chinese.

\section{(5) Other findings}

In addition to their life-long Chinese learning process, participants in this study, who were Chinese instructors, also shared some of their perspectives on the teaching and learning of Chinese language based on their own experiences. For example, Dr. Peter believed that learning a language is similar to learning other skills such as playing tennis or a music instrument. One needs to retain daily practice and overlearn in order to make the skill become automatic. As he put it:

Language learning is kind of like learning a musical instrument or learning a sport very well in that you have to learn it to a point of overlearning, you practice it to the point where it becomes automatic. It's a very different approach than content courses like sociology or history or something like that, where it's not that important to overlearn the skills. Anytime there's skill involved, you want to try to over learn it... same thing with athletics, you overlearn to the point where it just becomes natural; you don't have to think about the stroke, the slam or whatever, because you've done it so many times. I 
think with foreign language learning, because it's also a skill, you have to practice. With a coach in the sport, with a musical teacher learning an instrument,...having a conceptual understanding of something is not enough; you have to practice, practice, practice.

This view is well supported by the related literature (e.g., Snow, 2007; Stryker \& Leaver, 1997). In addition, Mr. Andy mentioned that because people learn things differently, it was very important for learners to find study methods that work best for themselves. He recalled that when he studied Chinese at college, he started a study group with his classmates after class on how to study Chinese, such as grouping Chinese characters with radicals. He stated that teachers should provide a variety of methods for students to choose what worked well for themselves. His view concurs with what Rubin and Thompson (1982) mentioned in their book.

Furthermore, similar to Stevick (1989) found from his study of the Chinese learner, both Mr. Andy and Dr. Sara in this study mentioned that repetition and recitation were necessary for Chinese learning. Mr. Andy recalled that when he studied in Taiwan he had classes in which teachers asked students to read texts after them, and he found it was a good way to improve pronunciation. Dr. Sara mentioned that for learning a language, one would have to memorize some text based on her learning and teaching experience. As she said:

For [learning] other European languages, it [memorizing some text] maybe is not necessary. But for our language [Chinese], which is really, truly, totally, foreign, it is necessary... This is how you developed template in your head, Doing through dialogues is easier than memorizing a list of vocabulary because you have an actual conversation, you have a situation, and it's more meaningful. At the same time, it gives you a framework for the sentence structures that you can refer back to even after class.

Mr. Andy and Dr. Sara also shared their insights on teaching grammar and communicative skills. They believed that the two aspects did not conflict. As Dr. Sara explained:

I do not think that classroom should be completely grammar based. You know, you want to be communicative. But I think having clear grammar explanation is very important for non-native beginners. They have to know, you know, it is really helpful for them to have grammar explanation but also to understand how this is related to what they do in English, explicit instruction about differences... As I tell my students at the beginning that you are adults, so you are not going to pick up accents as easily and nicely as little kids will, but you can think things abstractly and we are going to take advantage of that. We are going to analyze sentence structures abstractly, and this is something that you can do that little kids cannot, and you can benefit from it.

Mr. Andy concurred and used a good analogy to illustrate his view. As he said,

Grammar is the skeleton of a body, and if you are teaching only communicative, then they have the body part, but you may have a body that has no skeleton... But no one wants to do just the skeleton, because skeleton is scary, and not so much fun. You want to do the fun body-moving stuff, so you have to do a little bit of skeleton to be able to do more fun things with the body. 


\section{Conclusions}

Using the auto/biographical approach, in this study we interviewed six non-native Chinese instructors in the United States regarding their Chinese learning experiences. While each participant reached his/her success in their own way, we found many similar experiences and common themes among the participants. First, we found that most of the participants began to learn Chinese because of their intrinsic interest in Eastern philosophy and Chinese culture. Their initial motivation was also influenced by their family and community. To attract more potential students Chinese teachers, related administrators and practitioners are encouraged to organize cultural activities to promote Chinese language and cultural awareness in local communities, especially in areas where the Chinese community is small and there is short of resources on Chinese culture.

The study also found that all of the six participants took Chinese classes in college and what they learned in their local institutions helped build a foundation for their Chinese learning. Only two of them took Chinese classes prior to college. While literature shows that there are many advantages of learning a new language at an early age, many American college students do not have experience learning Chinese in their K12 education due to various reasons. The finding of this study is encouraging for those learners in that it shows that even though one begins to learn Chinese from college, s/ he can still possibly achieve high-level proficiency in Chinese and can even go on to become a Chinese instructor like participants in this study.

In addition, participants in this study all had experiences studying in mainland of China and/or in Taiwan. One of them also attended the summer immersion program at Middlebury College. They all held their immersion programs in high regard, and nearly all of them mentioned that study in such a program was critical in their Chinese learning career. Kubler (1997) suggests that study abroad experience should not be considered an optional plan for learning Chinese but an essential component of a Chinese learning curriculum. While it might be not realistic to require each Chinese major to study in Greater China at some universities, Chinese instructors, program coordinators and related advisors should at least encourage Chinese learners to study abroad as long as their financial condition permits.

It is worth pointing out that the immersion programs the participants in this study described were very rigorous and well designed. When organizing and/or recommending programs for students, instructors and related administrators need to pay attention to the design of the immersion programs, such as teacher qualification, pedagogy, as well as the interaction with peers. As Zeng (2011) notes in review of literature (e.g., Marriott, 1993; Rivers, 1998) on study abroad programs, sometimes "being there is not enough" (p. 32).

Furthermore, participants in this study were found to hold life-long learning attitudes toward their Chinese language learning, and use various strategies to self-regulate their learning throughout their learning careers. As Snow (2007) states, "learning a foreign language involves much skill components than learning many other school subjects" (p.27), the first task as a language instructor is to help students understand language learning. It is also imperative for a language educator to help students learn to build learner autonomy and self-regulate their learning in their language learning careers. The perspectives that the participants shared in this study on Chinese teaching and learning both as good language learners and as non-native Chinese instructors provide 
helpful implications for Chinese learners, instructors (native or non-native), researchers, as well as other practitioners and stakeholders.

Admittedly, this study has at least two limitations. First, as some researchers (e.g., Benson, 2011; Pavlenko, 2007) point out, one needs to "avoid treating narratives as factual accounts" (Benson, 2011, pp. 545-546). This in no way means that the participants were not telling the truth. Because the life-long learning processes span many years, and some incidents took place a very long time ago, there is the possibility that some participants might not have been able to recall what they did accurately. Second, there were only six interviewees in this study, and like all qualitative studies, readers need to be careful in generalizing the findings.

Despite these limitations, as partly discussed previously, this study nevertheless makes contributions to the field in three ways. First, it adds to the body of literature on Chinese language learners, especially helps to fill the gap on the study of good learners of the Chinese language. While there are publications available on studying of good learners of English and other commonly taught languages (e.g., Cotterall, 2008; Naiman et al., 1978; Norton \& Toohey, 2001), research on good learners of Chinese language, however, is still extremely limited. The experiences of good learners, as many scholars (e.g., Rubin, 1975; Griffiths, 2008a) have pointed out, can provide helpful implications for other language learners, their teachers as well as other related stakeholders.

Second, the study chose non-native Chinese instructors as good language learners, whose experiences can provide implications to practitioners and researchers of language teacher programs. Compared to non-native instructors in TESOL and commonly taught foreign languages in the United States such as Spanish and French, non-native instructors of the Chinese language are disproportionately rare. As Snow (2007) points out, there are many advantages of having local teachers, who can provide inspiration to learners through their own learning experience. It is our hope that our study can help motivate more successful Chinese language learners to join the Chinese teaching profession.

Finally, this study uses auto/biographical research method to collect narratives through interviews. One advantage of this approach, as previously discussed, is to help the participants to reflect on their long-term experiences (life stories) comprehensively within a short time (such as 45-60 min). While the approach has been used in TESOL (e.g., Wang, 2014), no study has been found in studying Chinese language learners yet. We hope that our study can help expand repertoires of researchers in the study of learning/teaching Chinese as a foreign/s language, a promising field where more research is needed.

\section{Endnotes}

${ }^{1}$ We use "Non-native Chinese instructor" in order to indicate that the native (first) language of these instructors is not Chinese, which does not reflect their Chinese proficiency level.

${ }^{2}$ Snow (2007) discusses learning and teaching of English. Local teachers in his book, accordingly, refer to non-native teachers from local countries, e.g. teachers who grew up in China teach English in China. The concept is the same in case of learning and teaching of Chinese. The non-native Chinese instructors in this article are local teachers, who grew up in the United States teach Chinese in the United States. 


\section{Appendix}

\section{Interview Protocols}

Prompts given to the interviewees at the beginning of the interview.

Think of your Chinese learning as a long story. Suppose you are writing a memoir on your Chinese learning experiences. How many chapters would you write? What would be the headings for each chapter?

The rationale of this is to strike a balance between the need to obtain a complete and rich narrative from you on the one hand, and the practical limitations of time and data on the other. Please take your time to think about it. You can use the following table as reference or create one on your own.

Chapter 1.

\section{Chapter 1.}

Chapter 2.

Chapter

Chapter 3.

Chapter 4.

Chapter 5.
Heading 1:

Heading 2:

Heading 3:

Heading 1:

Heading 2:

Heading 3:

Heading 1:

Heading 2:

Heading 3:

Heading 1:

Heading 2:

Heading 3:

Heading 1:

Heading 2:

Heading 3:

\section{Acknowledgements}

We would like to thank the six participants in this study for their generosity of sharing their incredible Chinese learning experiences with us, and thank the Dean's Office of College of Humanities and Social Sciences of Indiana University of Pennsylvania for partially funding the project.

\section{Funding}

The study was partially funded by the Dean's Office of College of Humanities and Social Sciences of Indiana University of Pennsylvania.

\section{Authors' contributions}

SL conceptualized the paper and initiated discussions with FW to conduct the study together by using similar method that FW used in his study on English language learners. SL and FW wrote the IRB together and reached out to recruit participants after receiving the IRB approval. SL successfully recruited six participants in the study and introduced one to FW. FW conducted the first interview by phone to establish the interview protocol and summarized the interview. SL interviewed the other five participants and wrote detailed summary with partial verbatim transcription for each of the six interviews. SL applied for a grant, and had the six interviews fully transcribed verbatim. SL and FW analyzed the data separately. FW wrote the first draft of the literature review section based on his previous study, and SL rewrote the literature review section by adding much more literature and restructuring the section. SL drafted the methodology and finding sections, and FW provided feedback for improvement. SL then wrote the first draft of the full paper, and FW offered suggestions on some wordings. SL also incorporated suggestions based on other colleagues and had two native speakers proofread the finalized paper. Both authors read and approved the final manuscript.

\section{Competing interests}

None of the authors have any competing interests in the manuscript.

\section{Publisher's Note}

Springer Nature remains neutral with regard to jurisdictional claims in published maps and institutional affiliations. 
Author details

${ }^{1}$ Department of Foreign Languages, Indiana University of Pennsylvania, Room 456, Sutton Hall, Indiana, PA 15705, USA.

${ }^{2}$ Statistics, Measurement, Assessment, \& Research Technology, Graduate School of Education, University of

Pennsylvania, 3700 Walnut St, Philadelphia, PA 19104, USA.

Received: 27 August 2017 Accepted: 4 January 2018

Published online: 19 January 2018

\section{References}

Bell, J. S. (2002). Narrative inquiry: More than just telling stories. TESOL Quarterly, 36(2), 207-213.

Benson, P. (2005). (auto) biography and learner diversity. In P. Benson \& D. Nunan (Eds.), Learners' stories: Difference and diversity in language learning (pp. 2-21). Cambridge, UK: Cambridge University Press.

Benson, P. (2011). Teaching and researching autonomy in language learning (2nd ed.; first published in 2001). London: Pearson Education.

Benson, P., \& Cooker, L. (2013). The applied linguistics individual: Gaining perspective. In P. Benson \& L. Cooker (Eds.), The applied linguistic individual: Sociocultural approaches to autonomy, agency and identity (pp. 178-186). London: Equinox.

Birdsong, D. (1999). Introduction: Whys and why nots of the Critical Period Hypothesis. In D. Birdsong (Ed.), Second language acquisition and the Critical Period Hypothesis (pp. 1-22). Mahwah, NJ: Erlbaum.

Block, D. (2003). The social turn in second language acquisition. Edinburgh: Edinburgh University Press.

Brecht, R. D., \& Walton, A. R. (1994). National strategic planning in the less commonly taught languages. In R. D. Lamber \& A. W. Heston (Eds.), The annals of the American academy of political and social science (pp. 190-212). Thousand Oaks, CA: Sage Publications.

Brumfit, C. (1995). Introduction to the new edition (vii-x). In N. Naiman, M. Fröhlich, H. H. Stern, \& A. Todesco (Eds.), The good language learner (new edition, first edition printed in 1978). Clevedon: Multiple Lingua Matters.

Brumfit, C. (1997). How applied linguistics is the same as any other science. International Journal of Applied Linguistics, $7(1), 86-94$.

Cohen, A. (1977). Successful second language speakers: A review of research literature. Balshanut-Shimushit: Journal of the Israel Association of Applied Linguistics, 1, 3-21.

Cohen, A. (2008). Preface. In C. Griffiths (Ed.), Lessons from good language learners (pp. 7-9). Cambridge: Cambridge University Press.

Cohen, A., \& Macaro, E. (Eds.). (2007). Language learner strategies: Thirty years of research and practice. Oxford: Oxford University Press.

Cotterall, S. (2008). Autonomy and good language learners. In C. Griffiths (Ed.), Lessons from good language learners (pp. 110-120). Cambridge: Cambridge University Press.

Cruickshank, K. \& Tsung, L. (2014). Teaching and learning Chinese: A research agenda. In L. Tsung \& K. Cruickshank (Eds.), Teaching and learning Chinese in an international context (pp. 213-224). New York, NY: Continuum International Publishing.

Dörnyei, Z., \& Ushiota, E. (2013). Teaching and researching: Motivation (2nd ed.). New York, NY: Routledge.

Duff, P., Anderson, T., Inyckyj, R., Van Gaya, E., Wang, R., \& Yates, E. (2013). Learning Chinese: Linguistic, sociocultural, and narrative perspectives. Berlin/ Boston: DeGruyter.

Ellis, R. (1994). The study of second language acquisition. Oxford: Oxford University Press.

Everson, M. E., \& Ke, C. (1997). An inquiry into the reading strategies of intermediate and advanced learners of Chinese as a foreign language. Journal of the Chinese Language Teachers Association, 32(1), 1-20.

Everson, M. E., \& Shen, H. H. (2010a). Editors introduction. In M. E. Everson \& H. H. Shen (Eds.), Research among learners of Chinese as a foreign language (pp.1-4). Honolulu: University of Hawaii: National Foreign Language Resource Center.

Everson, M. E., \& Shen, H. H. (Eds.). (2010b). Research among learners of Chinese as a foreign language. Honolulu: University of Hawaii: National Foreign Language Resource Center.

Everson, M. E., \& Xiao, Y. (2009). Introduction. In M. E. Everson \& Y. Xiao (Eds.), Teaching Chinese a foreign language: Theories and applications (pp.ix-xiv). Boston: Cheng \& Tsui Company.

Fallows, D. (2010). Dreaming in Chinese: Mandarin lessons in life, love, and language. New York, NY: Walker \& Co.

Fang, F. (2006). My experience of learning languages and teaching English in China: A narrative inquiry. English Teaching: Practice and Critique, 5(2), 117-129 Available online at https://edlinked.soe.waikato.ac.nz/research/files/ etpc/files/2006v5n2nar2.pdf

Firth, A \& Wagner, J. (1997). On discourse, communication, and (some) fundamental concepts in SLA research. The Modern Language Journal, 81(3), 285-300.

Gass, S. (1997). Input, interaction, and the second language learner. Mahwah: Lawrence Erlbaum.

Gass, S., Behney, J., \& Plonsky, L. (2013). Second language acquisition: An introductory course (4th ed.). New York, NY: Routledge.

Gil, J. (2014). An exploratory study of why language learners opt for Chinese and its competitiveness as a world language. Journal of the Chinese Language Teachers Association, 49(1), 51-93.

Grabe, W., \& Stoller, F. L. (1997). Content-based instruction: Research foundations. In M. A. Snow \& D. M. Brinton (Eds.), The content-based classroom: Perspectives on integrating language and content (pp. 5-21). White Plains, NY: Longman.

Graham, S. (1997). Effective language learning. Clevedon: Multiple Lingua Matters.

Griffiths, C. (2008a). Editor's overview. In C. Griffiths (Ed.), Lessons from good language learners (pp. 1-6). Cambridge: Cambridge University Press.

Griffiths, C. (Ed.). (2008b). Lessons from good language learners. Cambridge: Cambridge University Press.

Hall, J. K. (1995). (Re)creating our worlds with words: A sociohistorical perspective of face-to-face interaction. Applied Linguistics, 16(2), 206-232.

Hall, J. K. (1997). A consideration of SLA as a theory of practice: A response to firth and Wagner. The Modern Language Journal, 81(3), 301-306.

Han, Z. (2014). Preface. In Z. Han (Ed.), Studies in second language acquisition of Chinese (pp.ix-xi). Buffalo, NY: Multilingual Matters. 
Hanauer, D. (2011). Meaningful literacy: Writing poetry in the language classroom. Language Teaching: Surveys and Studies, 45(1), 105-115.

Hanban (2017). About Confucius Institute/Classroom. Retrieved from http://english.hanban.org/node_10971.htm

Jin, H. (1989). Language universals, language typology and L2 acquisition: A cross-sectional study of adult English speakers learning Chinese. Unpublished doctoral dissertation, University of Illinois. Retrieved from https://www. ideals.illinois.edu/handle/2142/23350

Jin, L. (2014). Peer/group interaction in a mandarin Chinese study abroad context. In Z. Han (Ed.), Studies in second language acquisition of Chinese (pp. 57-79). Buffalo, NY: Multilingual Matters.

Johnson, R. (1997). Examining the validity structure of qualitative research. Reprinted as appendix in F. Pyrczak (1999). Evaluating Research in Academic Journals (pp. 103-108). Los Angeles, CA: Pyrczak publishing.

Krashen, S. (1982). Principles and practice in second language acquisition. Oxford: Pergamon.

Kubler, C. (1997). Study abroad as an integral part of the Chinese language curriculum. Journal of the Chinese Language Teachers Association., 32(3), 15-30.

Lantolf, J. (1996). SLA theory building: Letting all the flowers bloom. Language Learning, 46(4), 713-749.

Lantolf, J. (Ed.). (2000). Sociocultural theory and second language learning. New York: Oxford University Press.

Lave, J., \& Wenger, E. (1991). Situated learning: Legitimate peripheral participation. Cambridge: Cambridge University Press. Lennenberg, E. (1967). Biological foundations of language. New York, NY: John Wiley.

Liu, J. (2010). Assessing students' language proficiency a new model of study abroad program in China. Journal of Studies in International Education, 14(5), 528-544.

Macaro, E. (2006). Strategies for language learning and for language use: Revising the theoretical framework. Modern Language Journal, 90(3), 320-337.

Marinova-Todd, S., Marshall, D. B., \& Snow, C. E. (2000). Three misconceptions about age and second-language learning. TESOL Quarterly, 34(1), 9-34.

Marriott, H. (1993). Acquiring sociolinguistic competence: Australian secondary students in Japan. Journal of Asian Pacific Communication, 4(4), 167-192.

McDonald, E. (2011). Learning Chinese, turning Chinese: Challenges to becoming sinophone in a globalised world. New York, NY: Routledge.

Naiman, N., Fröhlich, M., Stern, H. H., \& Todesco, A. (1978). The good lanquage learner (research in education series no. 7). Toronto: Ontario Institute for Studies in education.

Noels, K., Clément, L., \& Vallerand, R. (2000). Why are you learning a second language? Motivational orientations and self-determination theory. Language Learning, 50(1), 57-85.

Norton, B., \& Toohey, K. (2001). Changing perspectives on good language learners. TESOL Quarterly, 35(2), 307-322.

Oxford, R. L. (1990). Language learning strategies: What every teacher should know. New York, NY: Newbury House.

Oxford, R. L. (2010). Teaching and researching language learning strategies. New York, NY: Pearson Education Limited.

Oxford, R. L., \& Lee, K. R. (2008). The learners' landscape and journey: A summary. In C. Griffiths (Ed.), Lessons from good language learners (pp. 306-317). Cambridge: Cambridge University Press.

Pavlenko, A. (2007). Autobiographic narratives as data in applied linguistics. Applied linquistics, 28(2), 163-188

Pavlenko, A., \& Lantolf, J. (2000). Participation and reconstruction of selves. In J. Lantolf (Ed.), Sociocultural theory and second language learning (pp. 155-178). Oxford: Oxford University Press.

Prescott, C. \& Orton, J. (2012). Good Learners of Chinese - Profiles of students in secondary schools. Retrieved from http://education.unimelb.edu.au/_data/assets/pdf_file/0006/631599/good_language-learners-of-Chinese.pdf

Qin, X. (2014). Exploring the impact of culture in five communicative elements: Case of intercultural misunderstandings between Chinese and American. Journal of Intercultural Communication, 34. Retrieved from http://www.immi.se/ intercultural/nr34/xizhen.html.

Rampton, B. (1997a). Returning in applied linguistics. International Journal of Applied Linguistics, 7(1), 3-25.

Rampton, B. (1997b). Second language research in late modernity: A response to firth and Wagner. Modern Language Journal, 81(3), 329-333.

Rivers, W. (1998). Is being there enough? The effects of homestay placements on language gain during study abroad. Foreign Language Annals, 31(4), 492-500.

Roberts, B. (2002). Biographical research. Buckingham: Open University Press.

Rubin, J. (1975). What the "good language learner" can teach us. TESOL Quarterly, 9(1), 41-51.

Rubin, J., \& Thompson, I. (1982). How to be a more successful language learner. Boston, MA: Heinle \& Heinle Publishers,

Snow, D. (2007). From language learner to language teacher: An introduction to teaching English as a foreign language. Alexandria, Virginia: Teachers of English to Speakers of Other Languages, Inc..

Stern, H. H. (1975). What can we learn from the good language learner? The Canadian Modern Language Review, 31(4), 304-318.

Stevick, E. W. (1989). Success with Foreign Languages: Seven who achieved it and what worked for them. New York, NY: Prentice Hall.

Stoller, F. (2002). Promoting the acquisition of knowledge in a content based course. In J. Crandall \& D. Kaufman (Eds.) Content-based instruction in higher education settings (pp. 109-123). TESOL: Alexandria, VA.

Stoller, F. (2004). Content-based instruction: Perspectives on curriculum planning. Annual Review of Applied Linguistics, $24,261-283$.

Stryker, S., \& Leaver, B. (1997). Content-based instruction: From theory to practice. In S. Stryker \& B. Leaver (Eds.), Content-based instruction in foreign language education: Models and methods (pp. 3-28). Washington, DC: Georgetown University Press.

Tseng, M. (2006). Language gains in the study abroad and domestic contexts. Journal of the Chinese Language Teachers Association, 41(1), 57-78.

Tsung, L., \& Cruickshank, K. (2011). Emerging trends and issues in teaching and learning Chinese. In L. Tsung \& K. Cruickshank (Eds.), Teaching and learning Chinese in global contexts (pp. 1-10). New York, NY: Continuum International Publishing.

van Lier, L. (1997). Apply within, apply without? International Journal of Applied Linguistics, 7(1), 95-105. 
Vygotsky, L. S. (1978). Mind in society: The development of higher psychological processes. Cambridge, MA: Harvard University Press.

Wang, F. (2014). Autobiographical narratives on life-long English learning experiences by U.S. academics as multilingual subjects. Unpublished master's thesis. Indiana: University of Pennsylvania.

Wen, X. (1997). Motivation and language learning with students of Chinese. Foreign Language Annals, 30(2), $235-251$.

Wen, X. (2010). Acquisition of the displacement Ba-construction by English-speaking learners of Chinese. Journal of the Chinese Language Teachers Association, 45(2), 73-99.

Winke, P. (2007). The effect of L1 background on L2 Chinese learners' tonal production. Journal of the Chinese Language Teachers Association, 42(3), 21-55.

Yang, L. (2014). The effects of pragmatics instruction on L2 learners' acquisition of Chinese expressions of gratitude: A pilot study. Journal of the Chinese Language Teachers Association, 49(1), 95-115.

Zeng, Z. (2011). Second-culture worldview construction: Integrating in-class and out-of-class activity in in-china study. Unpublished master's thesis, Ohio State University. Retrieved from https://etd.ohiolink.edu/ap/10?0::NO:10:P10_ ACCESSION_NUM:OSU1308270341

Submit your manuscript to a SpringerOpen ${ }^{\circ}$ journal and benefit from:

- Convenient online submission

- Rigorous peer review

Open access: articles freely available online

- High visibility within the field

- Retaining the copyright to your article

Submit your next manuscript at $\gg$ springeropen.com 